\title{
Fauna on the maps of Russia and its Arctic Region
}

\author{
T.V. Vereshchaka ${ }^{\mathrm{a},}$, O.V. Kulagina ${ }^{\mathrm{b}}$, A.L. Stepanchenko ${ }^{\mathrm{c}}$ \\ ${ }^{a}$ Moscow State University of Geodesy and Cartography, Moscow, Russia, cartography@miigaik.ru \\ ${ }^{b}$ Moscow State University of Geodesy and Cartography, Moscow, Russia, olga.cartographer@yandex.ru \\ c Moscow State University of Geodesy and Cartography, Moscow, Russia, stalex@miigaik.ru \\ * Corresponding author
}

Keywords: Zoogeographical mapping, animal world, species biological diversity, matrix legend

Abstract:

Awareness of the importance of ever-growing environmental problems implies the need to study the relationship of biological, social, anthropogenic systems with nature. The environment of life is a complex multicomponent system and each of the components is a factor determining the state of the others, since all of them are interconnected with each other. Indicators of the state of ecological-geographical systems are organisms that create a biological environment, which requires the acquisition of relevant knowledge, including knowledge related to the field of zoology and zoogeography.

The authors have developed two new zoogeographic maps with elements of ecology. The first is the "Zoogeographic Map of Russia"(1:25 000 000) in the forthcoming edition of the Geographical atlas for secondary school teachers. The second is the "Animal world of the Russian Arctic Region (mammals)"(1:12 000 000) - a scientific map for the electronic edition of the National Atlas of the Arctic. Further, the principles of design and methods for creating these maps are revealed.

Approaches to the design of the educational "Zoogeographic Map of Russia" are based on the analysis of work programs that follow the Federal State Educational Standard. According to the requirements of these documents, pupils should know the animal population of Russia, the animal world of the native land, the natural zones of the country, altitudinal zoning, they should be able to give examples of the most indicative representatives of the natural zones, explain the species diversity of the animal world, know its taxonomy, and measures for protection. The guidelines for map design are proposed in accordance with these requirements and implemented in the author's original image (fig. 1).

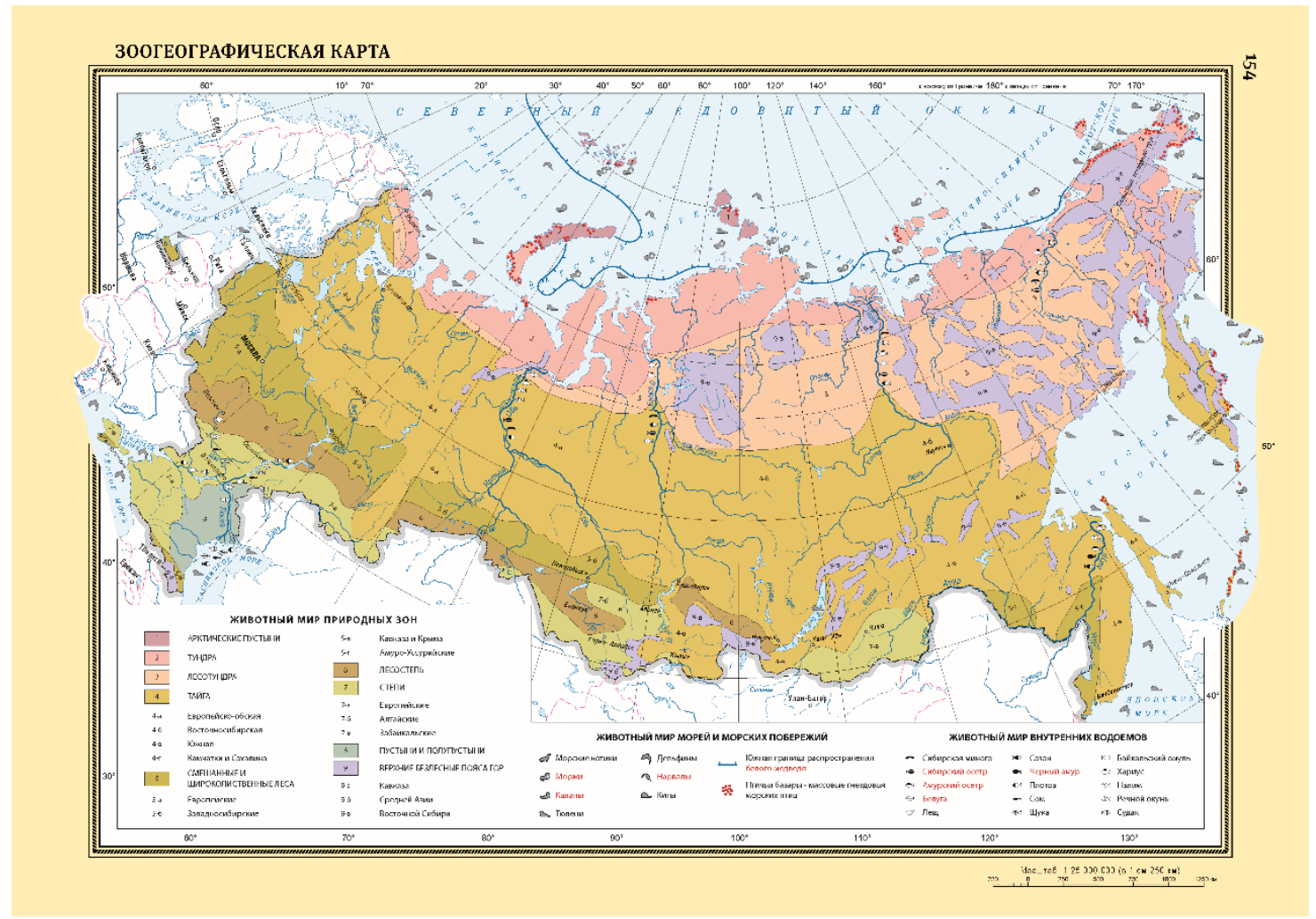

Figure 1. The original map and part of the legend reduced by 2,5 times

The thematic content of the map is based on the scientific systematics of the animal world. It covers the fauna of land, seas and sea coasts, and freshwater reservoirs. The map has a significant novelty and greater informative capacity in 
comparison with similar publications and a purpose surpassing the educational application. Selection of vertebrate animals includes not only mammals and birds, but also amphibians, cyclostomes, fishes and cetaceans. The image of the continental fauna is linked with the conditions of its habitat - natural zones, their parts, geographic areas with the identification of endemic and animals listed in the Red Book of Russia. The author's original is placed on two pages, of which map legend occupies a separate page in landscape format (fig. 2). It includes almost complete description of animals of all natural zones.

\section{1 Арктические пустыни}

Мл. Лемминг сибирский, песец, белый медведь, северный олень

Пт. Белая куропатка, белая сова

\section{2 Тундра}

Мл. Заяц-беляк, лемминг сибирский, норвежский лемминг, желтобрюхий лемминг, копытный лемминг, волк, песец, ласка, горностай, северный олень, овцебык

Figure 2. Animals of geographical zones (fragment of the legend)

The concept of the scientific map "Animal world of the Russian Arctic Region (mammals)" means defining the position of mammals in the organic world system, with animals being hierarchically differentiated from kingdom to species the basic unit of life forms system and the basic taxonomic element of mapping. Unlike most zoogeographical maps, displaying only land animals, the Arctic marine mammals are also the target of research and mapping. Further, the display of the relation between animals and their habitat landscape types (plain and mountain) is introduced into the map concept. The matrix form of the legend shown in the figure 3 with the map tile is subject to coverage of the variety of land animals. Both land animals and marine animals listed in the Red Data Book of the Russian Federation and regional Red Data Books of Russia highlighted on the map. The total of 85 mammal species of the unique Arctic Regions is listed on the map.

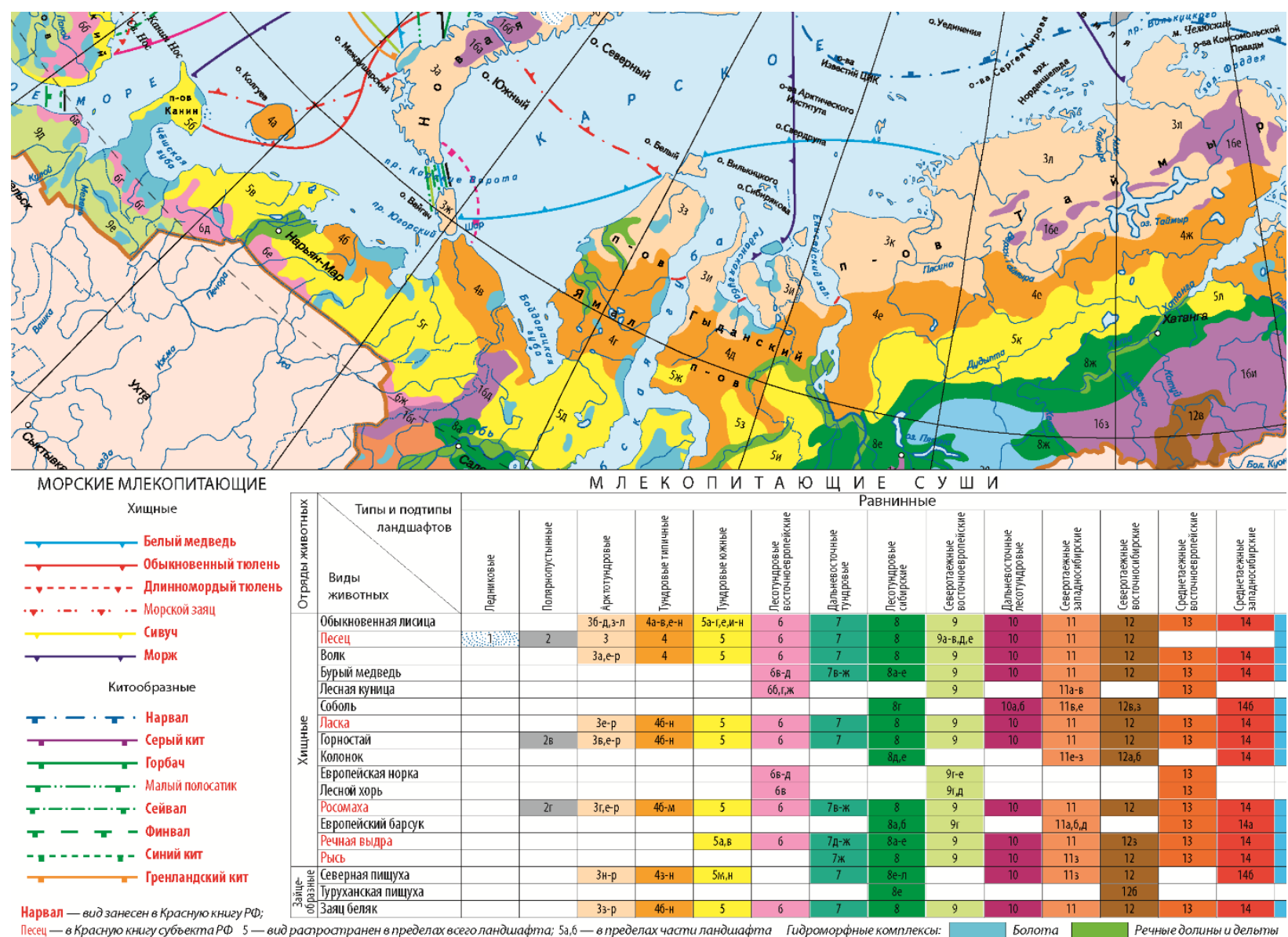

Figure 3. Fragment of the map

The results of performed mapping studies are essential for evolution of knowledge about the nature of Russia and its regions and for biodiversity conservation of vertebrate animals. 